\title{
Mbyá e Chiripá: Identidades étnicas, etnônimos e autodenominações entre os Guarani do sul do Brasil
}

\author{
Flávia Cristina de Mello
}

Resumo: A construção das identidades étnicas, etnônimos, autodenominações em aldeias Guarani nas regiões Sul e Sudeste do Brasil são aqui analisadas considerando o pensamento nativo a respeito. O presente artigo pondera sobre a coabitação e os elementos de distinção entre os Mbyá e Chiripá no Sul e sobre as diferenças entre os Chiripá e os Nhandeva no Paraná e São Paulo e destaca o conceito nhanderekó (um conjunto de normas e regras sociais e cosmológicas), que define o pertencimento a categorias étnicas e suas relações com os deslocamentos territoriais e/ou migrações. Palavras-chave: Identidades étnicas; autodenominações; Mbyá e Chiripá Guarani.

\begin{abstract}
The construction of ethnic identities, ethnic names, selfdenominations in Guarani villages in the regions South and Southeast of Brazil are analyzed here taking into consideration the native thought on the subject. The article in hand ponders on the mutual existence of distinctive elements among the Mbyá and Chiripá in the south and the differences among the Chiripá and the Nhandeva in Paraná and São Paulo and brings out the concept of nhanderekó, a collection of sociological and cosmological norms and rules, which define the belonging to ethnic categories and their relationships with the territorial displacements and/ or migrations.
\end{abstract}

Key words: Ethnic identities, Self-denominations, Mbyá and Chiripá, Guarani.
Doutora em Antropologia Social pela UFSC - Universidade Federal de Santa Catarina. Docente do Programa de Formação para Educação Escolar Guarani do sul e sudeste do Brasil Kuaá Mboé. Membro da Comissão Interinstitucional para Educação Superior Indígena (CIESI) da UFSC. flaviacdemello@yahoo.com.br 


\section{Introdução}

Este texto traz uma reflexão etnográfica sobre o processo de construção das identidades étnicas, etnônimos, autodenominações e descendências em aldeias Guarani do sul e sudeste do Brasil. Com base nas pesquisas por mim realizadas em aldeias Guarani durante os cursos de graduação, mestrado e doutorado ${ }^{1}$ e em minha participação como docente no Programa de Formação de Professores Guarani do sul e sudeste do Brasil Kuaá-Mboé ${ }^{2}$, aponto algumas considerações sobre o pensamento nativo a respeito de autodenominações e etnônimos das parcialidades Guarani ${ }^{3}$.

O recorte etnográfico, constituído pela análise de histórias de vida de pessoas Guarani que vivem nas aldeias pesquisadas e das relações de parentesco que orientam redes de deslocamento entre elas, possibilitou abordar a lógica interna da construção das autodenominações utilizadas atualmente pelas pessoas Guarani. Desta forma, problematizam-se as categorias utilizadas pela literatura etnológica clássica que divide os Guarani atuais em três parcialidades ou subgrupos, a saber: Kaiowá, Mbyá e Nhandeva.

A invisibilidade da etnia Chiripá é o primeiro ponto que quero abordar a partir deste enfoque. Os Chiripá do sul do Brasil, na literatura etnográfica ou ficam subsumidos entre os Mbyá ou são equivocadamente associados aos Nhandeva. Os Chiripá criticam tal invisibilidade e o desconhecimento por parte da sociedade nacional a respeito das diferenciações que possuem perante os outros subgrupos Guarani e vêm reforçando sua presença no contexto identitário entre os Guarani do sul do Brasil. Meus interlocutores Nhandeva também rejeitam a identificação dos dois grupos como sendo um único.

No Programa de Formação de professores Guarani do sul e sudeste do Brasil Kuaá-Mboé o tema das distinções entre as parcialidades Guarani são vivamente discutidas entre os alunos, pesquisadores/professores bilíngües, representantes de todas as aldeias Guarani que possuem escola nos estados de RS, SC, PR, RJ, ES. Para eles, as distinções entre Nhandeva, Chiripá e Mbyá e as semelhanças entre Chiripá e Mbyá têm sido tema de intensa reflexão. Um dos mais velhos professores Guarani e com mais tempo na profissão de professor bilíngüe, Sr. Agostinho, 62 anos, filho de pais Chiripá, define a sua percepção sobre o assunto:

Hoje a gente fala a mesma linguagem (os Mbyá e os Chiripá). Agora, antigamente o Chiripá já tinha outra linguagem diferente dos outros Guarani. Por exemplo, Werá Tudjá, meu pai, o velho pai ali que mora aqui em Biguaçu (SC), ele fala o Chiripá. Até eu muitas vezes não 
entendo a língua dele porque eu já tô morando a parte, já tô mais convivendo com outros guarani, vou dizer, os Tambeopé (uma das autodenominações do etnônimo Mbyá). É. Tem muitas diferenças a linguagem. Mas só que agora, nós não temos mais diferença, tá tudo misturado. Então é isso que nós estamos vivendo agora. O guarani é todos, Mbyá é todos, que chamam nós agora. Por isso que muitas pessoas dizem Chiripá ou Mbyá. É Chiripá, mas falam a mesma linguagem, o mesmo dialeto que o tal do Mbyá. Então não tem como a diferença. A única linguagem diferente que eu me lembro, quando eu fiz o estágio no Rio das Cobras (PR). Os Guarani lá era toda linguagem diferente. Lá são tudo o Nhandeva. A linguagem não era daqui. Eu entendia um pouquinho, mas eles não ocupavam o dialeto daqui do Sul. Tem uma explicação: Nhandeva, na nossa aldeia, quando fala assim, na nossa linguagem: 'Avakuery o' u' - chegou um guarani. Aí o mais velho fala: 'Mbyá? Nhandeva?'. Se fala Mbyá, aí a gente vai ter que saber que linguagem que vai usar com ele, porque é diferente de nós. Então se fala: 'o Mbyá chegou, né, chegou'. Então quer dizer que nós vamos saber que ele usa a linguagem Mbyá, então nós vamos ter que falar Mbyá com ele. Então, se é Nhandeva, talvez muitas palavras se vai falar com ele e ele não sabe ou pode ter outro sentido. É linguagem diferente. Diz que antigamente falavam Mbyá quando a pessoa é de fora, porque não pertence aquele povo. Se ainda não conhece né? Que não é nosso. É nesse sentido que entende Mbyá, que não é nosso, estrangeiro. Porque pode ser índio também, até se não faz parte da cultura guarani, então a gente chamava de Mbyá, estrangeiro... Hoje, Mbyá não existe, é tudo o Guarani.

Segundo Agostinho, atualmente as "linguagens" dos Chiripá e Tambeopé estão "misturadas". Tambeopé é uma autodenominação de um subgrupo que até pouco tempo atrás detinha uma "linguagem" própria, agora "misturado" com Chiripá. Os Tambeopé, assim como os Paim e até mesmo os Chiripá, são chamados Mbyá, etnônimo que vem tornando-se autodenominação geral para as etnias Guarani do sul em relações com a sociedade nacional. Para Agostinho, que é filho de Chiripás, a "linguagem dos Nhandeva", falada nas aldeias do Paraná, é considerada diferente da língua guarani "do sul". Nhandeva é a categoria usada para opor os "Nhandeva" aos "Guarani do sul", os Mbyá. Para marcar distinções lingüísticas de um visitante de uma aldeia distante pergunta-se: "Mbyá? Nhandeva?". Ambas são categorias generalizantes que distinguem dois grandes grupos Guarani pela linguagem usada por eles: A "linguagem do sul" e os Nhandeva.

A atual "mistura" entre as "linguagens" aparece em muitos discursos nativos sobre o tema. Em várias aldeias em que estive o processo histórico de coabitação e de alianças entre as famílias das diferentes etnias 
Guarani é enfatizado como uma maneira de evitar casamentos com nãoíndios e de colaboração entre "parentes". A "mistura" da linguagem é considerada pelas pessoas uma branda e incontornável conseqüência de um processo de resistência cultural fundamental. Entre os professores, por exemplo, busca-se resgatar as "linguagens antigas" 4 e, ao mesmo tempo, fortalecer esta linguagem franca.

Atualmente, as autodenominações exclusivas dos subgrupos Guarani do sul do Brasil são: Chiripá, Tambeopé e Paim. Muitas das pessoas que se autodenominam Tambeopé e Paim utilizam a categoria Mbyá para se autodenominarem diante dos não-indígenas. Mbyá é uma autodenominação inclusiva mesmo aos Chiripá, por entenderem ser esta uma categoria utilizada pelos não-indígenas como sinônimo de 'Guarani'.

Um professor Nhandeva do Paraná define a diferença entre os Nhandeva e Chiripá como sendo baseada na distinta linguagem e na forma de organização social de uma aldeia, o "sistema". Segundo ele:

OChiripá e o Mbyá para nós são o mesmo, é o guarani do sul né. (...) Eu acho que o Chiripá e o Nhandeva não podem ser o mesmo. A fala é diferente da nossa e a reza o sistema a gente vê que também tem diferença. Tem outro sistema. Mas é tudo o guarani também. Agora, fala igual a nossa é do guarani de Nimuendaju (antiga aldeia Araribá, em Bauru, no estado deSão Paulo, onde mora sua mãe), ou do Mato Grosso, eu conheço o guarani de lá. Lá é o Nhandeva mesmo. Guarani do sul é diferente, não é o Nhandeva. Agora eu já vi nos livros que para os brancos eles também são chamados de Nhandeva...

Para Claudinei, vale a mesma oposição trazida por Agostinho: A "fala" (e o "sistema") Nhandeva, relacionados às aldeias Guarani de São Paulo e Mato Grosso do Sul e a "fala" dos Mbyá e Chiripá, o guarani "do sul". Ele e outros professores Guarani que têm pesquisado o tema das distinções culturais e lingüísticas entre os subgrupos Guarani estão produzindo interessantes interpretações sobre o processo histórico e cultural de construção destas distinções.

Para as pessoas das aldeias onde estive, as distinções étnicas, etnônimos e autodenominações utilizadas, desde o início de minhas pesquisas, colocaram-se como de difícil consenso. As respostas à minha pergunta: "Você se define como Guarani Mbyá, Nhandeva ou Chiripá?" tinham muitos níveis. Em um nível superficial, de interação com um djuruá indistinto, a resposta imediata será ligada à etnia com a qual a liderança política da aldeia se identifica. Na cidade ou em interações com visitantes nas aldeias, os moradores vão construir uma imagem de um grupo identitário monolítico, a não ser que seu grupo familiar esteja em diver- 
gência declarada com posturas políticas e/ou religiosas das lideranças. Em um nível mais profundo, quando a pergunta é feita correlacionando parentesco e descendência, como tenho trabalhado, as respostas dificilmente são diretas, como: "Sou Mbyá", por exemplo. Em geral, as pessoas devolvem à pergunta uma reflexão sobre a construção destas categorias, ponderando sobre a mestiçagem entre as parcialidades guarani e explicitando o aspecto social ferramental das categorias de distinções étnicas, como as duas falas acima exemplificam.

Os Chiripá, hoje, estão muito próximos dos Mbyá, espacial e parentalmente, a ponto de muitas vezes, vários de meus interlocutores Guarani ficarem em dúvida se são "mais Chiripá ou mais Mbyá", devido aos elementos históricos e culturais aos quais me refiro a seguir, como a coabitação histórica e o grande intercurso matrimonial entre os dois grupos. Nestes casos, o pertencimento a um ou a outro grupo deve-se a conjunturas locais, baseados em aspectos morais, políticos, religiosos e familiares.

No aspecto cultural, pode-se constatar etnograficamente distinções entre os Chiripá e os Nhandeva mais contundentes do que as diferenças entre os Mbyá e os Chiripá, expressas, por exemplo, pelas características rituais, mitológicas, de cultura material.

Diante desta conjuntura exposta acima, a invisibilidade Chiripá é reforçada pelo fato da maioria das aldeias de RS e SC, onde os Chiripá coabitam com os Mbyá, serem denominadas pelos djuruá (instituições governamentais, ONGs, pesquisadores, etc.) como sendo aldeias Mbyá (em vários casos em consonância com as próprias lideranças das aldeias, que entendem ser essa a autodenominação mais favorável politicamente.) Esse aspecto evidencia uma questão conceitual que empobrece a compreensão da realidade atual das aldeias Guarani, na medida em que restringe a compreensão da diversidade interna à organização social das mesmas. Para muitos destes interlocutores não-indígenas, Mbyá é sinônimo de um grupo étnico mais "autêntico", que melhor representa os Guarani. Este entendimento já foi percebido pelas pessoas das aldeias, que valemse da categoria Mbyá, quando querem reforçar sua indianidade.

\section{Breve Histórico sobre etnônimos e autodenominações Guarani}

Os etnônimos das etnias indígenas nas Terras Baixas da América do Sul têm sido algo controverso desde os primeiros registros ocidentais sobre estes povos. Do século XVI aos dias de hoje, os viajantes, literatos e 
posteriormente, estudiosos e cientistas, vêm designando grupos indígenas por nomes obtidos das mais diferentes formas. A maioria dos etnônimos encontrados nestes registros históricos para identificar os diferentes povos indígenas eram nomes atribuídos por outros e não um nome adotado pelos próprios. Usava-se, por exemplo, uma característica mais evidente do grupo denominado, como no caso Chiripá, que se refere a um tipo de vestimenta usada antigamente. Outras vezes, eram nomes atribuídos a um grupo por seus vizinhos ou inimigos e, nesses casos, são alcunhas consideradas pejorativas pelo próprio grupo, como no caso do etnônimo Kaiowá, que significa comedor de macaco, por exemplo. Por isso, etnônimos históricos dificilmente coincidem com a autodenominação dos grupos, são alcunhas e não nomes próprios. E em muitos casos, os etnônimos que permanecem historicamente passam a ser usados pelas pessoas da etnia por eles nominadas como autodenominações. Outras dessas denominações são rejeitadas pelos grupos indígenas por elas identificadas.

Continuidade e desaparecimento de etnônimos dentro da etnia Guarani complexifica comparações históricas entre os subgrupos Guarani do passado e os atuais. Nos últimos cinco séculos, etnias emergiram e desapareceram do grande etnônimo Guarani. O etnônimo "Mbyá", por exemplo, aparece pela primeira vez na literatura por volta da metade do século XIX, designando os Guarani habitantes da região do Rio Mondai no Paraguai (Garlet, 1997), contudo, o grupo assim nominado poderia estar em outros lugares, com outras denominações. No início do século XX, o etnônimo Mbyá é usado para denominar grupos no litoral de São Paulo, conforme relato sobre a família de Guarani que Nimuendajú acompanhou em uma pequena parte de seu deslocamento até o litoral (Nimuendajú, 1987).

Recentemente, as parcialidades ou subgrupos Guarani descritos em grande parte da literatura etnográfica das quatro últimas décadas passaram a ser resumidas segundo as categorias definidas por Schaden (1974), que define os Guarani no Brasil divididos em três subgrupos: Kaiowá, Mbyá e Nhandeva (ou Chiripá). Em Aspectos Fundamentais da Cultura Guarani, a partir de seu campo nas décadas de 1940 e 1950, ele descreve "a existência de três dialetos Guarani em território brasileiro", que são:

Nhandeva é a denominação de todos os Guarani (...) é a única autodenominação usada pelas comunidades que falam o dialeto registrado por Nimuendajú com o nome Apapokuva (...) e também pelos Tanyguá e outras hordas mencionadas por aquele autor. Proponho, por isso, que se reserve o nome Nhandeva para essa subdivisão. Pelos Mbüá é apeli- 
dada de Tchiripá í"(...) Mbüa é a autodenominação mais usada pelos Guarani conhecidos na bibliografia como Kainguá, Kaiuá etc. e que os Nhandeva chamam Tambeaopé (...) (Schaden, 1974, p.2-3).

Segundo este autor, portanto, Nhandeva seria um etnônimo generalizante que podia englobar todos os Guarani, mas que contudo, era a autodenominação de grupos registrados na literatura como Apapokuva, Tanyguá e outros. Tchiripá seria a forma com que os Mbyá chamavam os referidos grupos. E Mbyá seria a autodenominação dos grupos tratados por Kainguá nas bibliografias e de Tambeopé pelos Nhandeva.

Atualmente, para os Chiripá, Nhandeva é uma palavra genérica para designar os seres humanos. Para eles é depreciativo se autodenominar desta forma, pois entendem Nhandeva como "qualquer Guarani", ou "qualquer ser humano" (nhande - nós, ava - homem, ser humano). Alguns grupos Guarani em Mato Grosso do Sul também rejeitam este etnônimo, utilizando a autodenominação 'Guarani' para distinguiremse dos Kaiowá. Já para os Nhandeva que assim se denominam, como o caso de pessoas na aldeia Laranjinha, no Paraná, Nhandeva é sinônimo de "nós, os humanos verdadeiros". No Paraguai, os grupos chamados de Chiripá autodenominam-se Ava-Katu-eté, "os autênticos, os verdadeiros humanos" (Bartolomé, 1977), sinônimo da tradução dada ao termo Mbyá pelos Guarani que atualmente assim se autodenominam. Para os Apapocuva, Mbyá significa "gente", mas no sentido pejorativo, de "gente atrasada", "ralé” (Nimuendajú 1987,7), enquanto para os Mbyá e Chiripá atuais significa "os Guarani verdadeiros".

Autodenominações do tipo "gente", "nós, os humanos, os verdadeiros humanos" etc. é uma constante para vários povos indígenas, como os Araweté, os Yaminawa, os Waiapi e muitos outros. Viveiros de Castro (Viveiros de Castro 1996, 126), propõe que estas alcunhas autoreferenciais são pronomes cosmológicos e não nomes próprios. Eles servem para marcar o lugar de onde se fala, o nós do grupo, como no caso de nhande e ore na língua Guarani, por exemplo. Os dois termos significam nós $\left(1^{\mathrm{a}}\right.$ pessoa do plural). Contudo, nhande é um termo inclusivo, refere-se a qualquer "nós" e ore é um termo exclusivo, que refere-se apenas a um nós específico, muitas vezes ligado à categorias étnicas.

O discurso nativo sobre estas distinções define diferentes patamares do 'ser Guarani'. Existe o reconhecimento de uma identidade étnica Guarani ampla e inclusiva. Para meus interlocutores, falar guarani, morar numa aldeia organizada conforme alguns preceitos culturais, reconhecer os mesmos deuses e rituais, são evidência de pertencimento à identidade étnica Guarani, o nhanderekó. Este pertencimento equivale ao reconheci- 
mento de um grupo específico, um "povo" que se diferencia social e cosmologicamente de todos os outros povos indígenas ou não indígenas do mundo. As identidades exclusivas estão ligadas à genealogia, linguagem e distinção de normas e condutas sociais, que refletem o local de nascimento e a história de vida das pessoas.

\section{Autodenominações, descendências e afinidades}

Os Chiripá reconhecem-se descendentes dos antigos Guarani habitantes do litoral e dos vales dos rios do oeste dos estados do sul, com o Rio Paraná, o Uruguai e seus afluentes. Reconhecem-se também como parentes dos Tambeopé e os Paim, os Mbyá que chegaram ao litoral e efetivamente, a maioria das pessoas das famílias Mbyá têm relações de parentesco com pessoas Chiripá e vice-versa. A uma pessoa filha de Mbyá e Chiripá não é posta em dúvida sua identidade Guarani. Contudo, seu pertencimento a uma ou a outra etnia é construída no decorrer de sua vida e dependerá de qual parte da família interferiu mais na educação da pessoa, de qual dialeto ela domina melhor, como é sua reza e do contexto social em que esta identidade será definida.

Mbyás e chiripás definem-se um em distinção ao outro, não como inimigos ou vizinhos em reciprocidade negativa, mas ao contrário, como outros que definem-se "parentes" entre si e realizam amplas relações de reciprocidade positiva. Nesta associação, estes subgrupos apoiaram-se mutuamente em um processo histórico de "reterritorialização" (Garlet, 1997) que dura cerca de 150 anos. As famílias Chiripá do litoral “seguraram" as terras dos antigos parentes e as famílias Mbyá vindas do oeste passaram a estabelecer relações de afinidade e reciprocidade com elas, associando-se em uma rede de circularidade e reciprocidade entre as aldeias, alimentadas pelos deslocamentos territoriais das pessoas. Esta rede é formada por "famílias anfitriãs", que permanecem numa aldeia por décadas "segurando" a terra, enquanto várias "famílias visitantes" circulam entre as aldeias, criando relações de aliança e/ ou reciprocidade entre si.

Distinguir um Guarani de um não-guarani é simples: Desconhecer a língua é o sintoma mais evidente de não pertencimento ao universo Guarani. Ser filho de pai e mãe Guarani (não ser mestiço) é outro sintoma, que será, porém, atenuado se desde a infância a criança viver entre os Guarani e compartilhar seu modo de ser. Distinguir um Chiripá de um Mbyá, quando ambos moram na mesma aldeia e são descendentes de 
ancestrais comuns, não é uma tarefa assim tão fácil, sequer para os próprios Guarani.

A autodenominação étnica que cada pessoa assume para si é composta por vários elementos e é pensada e construída em distintos níveis. Quando esta pergunta é formulada por um não-indígena, esta chega ao interlocutor guarani carregada de um apelo político, uma vez que há uma longa luta das lideranças nas aldeias em que trabalhei, para obter junto à sociedade nacional o reconhecimento dos direitos sobre suas terras e sua decorrente demarcação. Neste contexto, declarar-se Mbyá ou Chiripá pode ser visto como uma forma de reforçar a imagem de coesão do grupo. Os Guarani valem-se destas categorias, porque constataram que a sociedade envolvente não compreende suas autodenominações. O prestígio que a etnia Mbyá tem obtido junto aos órgãos governamentais, instituições e pesquisadores não passa despercebido dentro das aldeias. Muitas pessoas que reconhecem-se Chiripá, em eventos, reuniões, entrevistas, etc. autodenominam-se Mbyá por compreender que os djuruá associam a palavra Mbyá a um sinônimo de Guarani e desconhecem a palavra Chiripá

Internamente há certo grau de divergência na definição do que é ser um Chiripá ou um Mbyá até mesmo entre duas pessoas da mesma etnia. Os interlocutores mais jovens confessaram-se confusos ao estabelecer o que diferencia um Mbyá de um Chiripá, afirmando que só os velhos são capazes de refletir com mais propriedade sobre o assunto. Contudo, quando as pessoas com quem interagi durante a coleta de dados para minha pesquisa percebiam que as minhas perguntas sobre distinções entre Chiripá e Mbyá vinham atreladas a um interesse de compreensão da história da família e não a questões eminentemente políticas, elas dispunham-se a refletir mais profundamente sobre o tema.

A mestiçagem genealógica, mas também cultural e lingüística, entre os dois grupos, ocorridas nos dois últimos séculos é um dos aspectos principais na complexificação das distinções entre Mbyá e Chiripá, porque uma das diferenças mais notáveis estaria na língua. Este processo histórico de coabitação e intercursos matrimoniais configurou a realidade das aldeias do século XXI de tal modo que algumas categorias identitárias estão tendo seu sentido reelaborado. Quando o principal critério nativo de diferenciação é a língua, a fronteira entre o "nós" e os "outros" é muito tênue, quando todos falam o guarani de forma muito semelhante. Diferenças que antes eram marcantes, agora reduzem-se a distinções sutis de vocabulário e sotaque.

Distinguir um Guarani de um não-guarani é simples: Desconhecer a língua é o sintoma mais evidente de não pertencimento ao universo 
Guarani. Ser filho de pai e mãe Guarani (não ser mestiço) é outro sintoma, que será, porém, atenuado se desde a infância a criança viver entre os Guarani e compartilhar com seu modo de ser. Distinguir um Chiripá de um Mbyá, quando ambos moram na mesma aldeia e são descendentes de ancestrais comuns, não é uma tarefa assim tão fácil, sequer para os próprios Guarani ${ }^{6}$. Segundo meus interlocutores, os Mbyá e Chiripá possuem falas distintas, que diferenciam-se, contudo, em poucos aspectos. Agostinho Moreira afirma que na sua aldeia (Estiva-RS) não há distinção quanto à linguagem, a diferença seria marcada apenas genealogicamente. Para Etelvina Fontoura, filha de mãe Mbyá, mas que viveu afastada da vida das aldeias por algum tempo, moradora da aldeia Cambirela (SC), "o Mbyá fala diferente do Chiripá da mesma maneira que um paranaense fala diferente de um gaúcho". Ela se autodenomina apenas "Guarani".

A forma com que se vive é outro traço que os diferencia. A prática do nhanderekó, ${ }^{7}$ o modo de ser Guarani, indica níveis de competência que definem o que é ser "guarani de verdade", de viver "como os antigos". O vocabulário cotidiano e ritual seria outra diferença (assim como os deuses aos quais se reza), condutas sociais, tabus alimentares, total rejeição aos valores exógenos (em especial a tudo que venha do mundo dos "djurua" (sociedade nacional) e, fundamentalmente, uma vida voltada à espiritualidade e às práticas rituais), definem estes níveis como sendo de maior ou menor competência. Chiripás e Mbyás têm papéis definidos diante do conjunto de normas e regras sociais decorrentes destes preceitos de nhanderekó. Nas falas ouvidas nas aldeias, dos Chiripá, em oposição aos Mbyá, espera-se uma maior capacidade de interlocução com outros povos, são considerados mais "briguentos", mais falantes, praticantes assíduos de djerodji (danças) de lutas, como o tchondaro e o nhemointin, permitem-se menos rigor em tabus alimentares (podendo mesmo comer a comida do "branco" ou de outros índios sem se contaminar ou adoecer), com rituais menos austeros e dedicados a um panteão muito mais amplo de deuses etc. Dos Mbyá, espera-se mais rigor no respeito às regras de conduta, comedimento, isolamento. Eles devem ser os guardiões da maneira antiga de viver, sem falar as línguas dos brancos, sem casamentos inter-étnicos, sem idas constantes à cidade, evitando conflitos e sentimentos de ira, entre outros.

Na visão Chiripá, a autodenominação Mbyá, que para os Chiripá também traduz-se por "Guarani verdadeiro", pode ser reivindicada por pessoas pertencentes à qualquer etnia Guarani, sempre que estas pessoas julgarem viver dentro dos preceitos sagrados ditados por Nhanderú e Nhandecÿ (divindades supremas), ou o mais próximo possível deles. Deste 
ponto de vista, autodenominar-se Mbyá é uma prerrogativa de qualquer Guarani "verdadeiro".

Portanto, a autodenominação Mbyá, não define apenas uma etnia, em sua acepção mais abrangente e sim um grupo moral, que marca sua identidade pela competência em realizar uma série de princípios sociais e rituais. É um gradual que se consolidada por meio das condutas diárias, das alianças, do que se come, de como se fala, de com quem se casa e com quem se vive.

\section{Considerações finais}

Dentre as condutas preconizadas pelo nhanderekó, o oguatá (hábito de deslocar-se) é fundamental, pois funciona como uma forma de restabelecer a ordem cosmológica e social abaladas por algum evento e fundar novas terras livres destes males. No discurso nativo atual, os deslocamentos territoriais são associados diretamente à busca do nhanderekó e possuem um espectro muito amplo de conexões com a estrutura social. A "busca da terra sem mal", que por tanto tempo permeou a literatura sobre os deslocamentos Guarani, atualmente mostra-se periférica, contudo associada a essa busca pelo nhanderekó, este sim, elemento cosmológico central na definição deste ethos migratório dos Guarani ${ }^{8}$. A busca do nhanderekó define várias orientações de fundo cosmológico sobre aspectos ambientais e práticas sociais, propicia a busca de condições materiais e sociológicas para realização de comportamentos sociais, preceitos morais e de modo de produção.

Para as pessoas das aldeias em que trabalhei, seus deslocamentos, ou seja, as várias mudanças de local de viver que realizam durante suas vidas, definem sempre a superação de uma situação desfavorável ou de busca de uma situação desejável. $\mathrm{O}$ ato de deslocar-se de uma aldeia para outra, seja só em busca de um cônjuge ou de parentes, ou com a família, abandonando uma terra por alguma mazela, é visto como um mecanismo de preservação cultural, uma forma de luta para a manutenção do nhanderekó, ou orerekó (o "sistema Guarani", o modo de vida próprio da cultura Guarani).

As narrativas de pessoas Chiripá e Mbyá com que trabalhei indicaram que o "caminhar" (oguatá) é uma conduta própria dos Guarani, preconizada pelos deuses ${ }^{9}$ e que em si já consiste em uma conduta sagrada que reforça os laços com as divindades, purificando e fortalecendo o espírito. Propicia também a realização de condutas e normas 
sociais indispensáveis ao "seguir sendo Guarani", uma forma de buscar condições de levar uma vida mais adequada aos preceitos culturais e de se afastar, obviamente, dos problemas que os ameacem. Para além do discurso socio-político e cosmológico-religioso relacionado a este ethos migratório, há também o discurso identitário, uma vez que a busca que parece mover os Guarani atualmente é a busca por uma terra que permita viver dentro dos preceitos sociais sagrados da cultura Guarani, do nhanderekó, e só aqueles que vivem conforme o nhanderekó podem considerar-se Guarani "verdadeiro" independentemente do pertencimento a uma ou outra etnia.

Dentre estas condições para a manutenção do nhanderekó estão um conjunto de regras e condutas sociais, como preceitos matrimoniais que rejeitam casamentos inter-étnicos e estabelecem relações de reciprocidade entre as aldeias pelas quais as pessoas circulam. É através deles, por exemplo, que se estruturam arranjos matrimoniais, (em grande parte dos casamentos entre jovens, o rapaz circula pelas aldeias da rede de parentesco de sua família colateral, em busca de uma noiva. Ao encontrála, ele passa a viver na terra de seus parentes afins). E são as redes de parentesco e reciprocidade que orientam as rotas de deslocamentos pelas quais seguem as famílias em suas migrações, que se dão sempre para "terra de parentes". Os deslocamentos propiciam também um amplo sistema de troca de informações, notícias sobre as aldeias distantes, conselhos de conduta e resolução de problemas com os grupos envolventes, troca de sementes, víveres e artesanato, sementes sagradas, curadores e seus pacientes, enfim, os bens e saberes que circulam nas redes que unem as aldeias Guarani em um sistema de reciprocidade que chamo de complexos de "aldeias-irmãs" (Mello, 2006).

Entretanto, as conjunturas atuais dificultam o pleno exercício do nhanderekó. Diante do fato de que "o mato está acabando", o que impossibilita viver da mesma forma com que viviam os antigos Guarani, tornase necessário encontrar novas estratégias que permitam continuar vivendo no mínimo possível de acordo com o nhanderekó. Dentre estas estratégias está a necessidade de garantir algumas porções de terra com condições de fornecer os elementos necessários a tais preceitos, de conhecer a "lei dos brancos", de obter a demarcação das terras em que vivem, para nelas estabelecerem as tekoá porã (as aldeias boas). As tekoá porã são aquelas aldeias capazes de fornecer condições ambientais e materiais que subsidiem esta organização social, terras adequadas à realização das roças tradicionais, como milho, mandioca, feijão, batata doce, etc. e do manejo de elementos fauna e flora característica à dieta alimentar Guarani, como 
por exemplo, uma mata onde se possa manejar as árvores sagradas como o cedro, a palmeira pindó e a tarumã, ervas medicinais e se possa praticar a caça com mundéo (armadilha tipo arapuca), enfim, condições de manutenção de uma dieta alimentar e um sistema de cura, próprios da cultura Guarani, um fator extremamente importante no equilíbrio social e de saúde individual das pessoas.

Estratégia privilegiada de manutenção do nhanderekó, o hábito de deslocar-se, de mudar de aldeia várias vezes durante a vida, a forma e freqüência com que são realizados, diferencia Mbyá e Chiripá. Deslocarse com freqüência é considerado característico das famílias Mbyá, em oposição a uma postura mais sedentária dos grupos Chiripá ${ }^{10}$. Esse aspecto marca uma postura política distinta de relacionamento com os nãoindígenas e com as leis da sociedade nacional brasileira: Uma de evitar o contato e o embate, outra de persistir e lutar pela garantia dos direitos sobre suas terras. Não por acaso, as famílias anfitriãs, são majoritariamente Chiripá e as visitantes, Mbyá. A definição “antiga” do termo Mbyá como "estrangeiro" descrita nas páginas anteriores na fala de Agostinho Moreira, explicita uma questão sociológica interessante: Chiripá e Mbyá são grupos complementares na organização social de uma aldeia. Os Chiripá estão ligados ao centro, à articulação, à política ${ }^{11}$. Os Mbyá estão nas margens, são visitantes, efêmeros, "do mato" e por isso controlam o núcleo duro da tradição, a língua antiga, a religiosidade sem interferências, o afastamento de outras etnias, a endogamia cultural. Não se trata de ser "mais ou menos Guarani", são os dois lados da mesma moeda, relação necessária para a continuidade das aldeias atuais.

Apesar de nem sempre se confirmar na prática, o discurso sobre os deslocamentos é muitas vezes construído pelos narradores Guarani como sendo algo característico ao ethos Mbyá, em oposição a uma postura menos afeita a constantes deslocamentos, associada aos Chiripá. A complementaridade entre os dois grupos indica o porquê de tão recorrente relação de coabitação: as condutas Mbyá e Chiripá são complementares como as condutas do karai (xamã) e do tchondaro (guerreiro, caçador), em uma oscilação entre centro e periferia. O Chiripá é o centro político (família anfitriã), é o guerreiro, enfrenta os inimigos, fala a língua do outro, e pode até mesmo estabelecer relações de afinidade com o outro, luta pelos direitos de permanência em suas aldeias. O Mbyá é a periferia, é a família visitante, é o efêmero, o que está sempre pronto a se esquivar das relações e embates com os não-Guarani e vale-se para tal das migrações. Não fala a língua, não come a comida, não casa com o outro. Contudo, Chiripá e Mbyá dependem mutuamente da reciprocidade que estabelecem entre si 
para seguirem vivendo dentro "dos costumes dos Guarani antigos", do nhanderekó. É comum encontrar aldeias onde a liderança política é Chiripá e a liderança religiosa é Mbyá ou vice-versa.

Estas oposições funcionam hoje como alegorias às antigas identidades dos primeiros povos criados pelos deuses: Chiripá e Mbyá são como dois irmãos que caminham juntos. Um mais velho e mais sensato, outro mais jovem e aventureiro, mas que juntos se complementam, como Sol e Lua, dois irmãos que protagonizam as diversas aventuras do corpus mítico Guarani. Os mitos Mbyá associam o hábito de deslocar-se aos hábitos divinos praticados pelos deuses, quando moraram nesta terra, e que hoje é preconizado por eles aos seus "filhos caçulas", os Mbyá, "aqueles criados no centro da terra" (Yvy mbyté). Na mitologia Mbyá, Yvy Mbyté é um lugar ancestral, onde os deuses criaram a humanidade verdadeira, os Mbyáeté'i, para espalharem-se pelo mundo. Os Chiripá, que em oposição aos Mbyá identificam-se como habitantes do litoral desde um passado remoto, em sua mitologia reconhecem yoy mbyté como o centro da terra e local de criação da "humanidade verdadeira" (orekuery etê). Entretanto, contestam a autodenominação de Mbyá para o grupo que atualmente assim se define. Para os Chiripá, Mbyá é um termo que qualifica um povo Guarani muito antigo, que foi de fato criado em Yoy mbyté, onde "os brancos" chamam de Paraguai. Porém, atualmente, afirmam os Chiripá, só pode se dizer Mbyá quem vive realmente de acordo com o nhanderekó. Nhanderekó ou orerekó é a maneira ideal de um Guarani viver, segundo os mitos sagrados, seja esta pessoa pertencente à "raça" Guarani Chiripá, Paim, Tambeopé ou Guarani Paraguaia.

É importante registrar que estas discussões a respeito das distinções nativas entre os subgrupos Guarani não são tema explorado com freqüência pela literatura Guarani e que aqui estão ilustrados por dados etnográficos recentes e específicos. Diante de tantas nuances entre as diferentes identidades apresentadas por meus interlocutores Guarani, resumo as distinções entre as três etnias Guarani do sul do Brasil, proponho as seguintes sistematizações: O processo histórico de mobilidade Mbyá evidencia a estratégia de alteração espacial e constância identitária. A oposição extrema a essa conduta seria representada pelos Nhandeva, com constância espacial e alteração identitária (explicitada pela inserção de língua e religião externas). Na mediação entre as duas identidades estão os Chiripá, aliando relativa constância espacial e identitária, hoje em estreita associação aos Mbyá e distanciamento dos Nhandeva. 


\section{Notas}

${ }^{1}$ Minha pesquisa etnográfica entre os Guarani iniciou-se em 1997, durante minha graduação no curso de Ciências Sociais na UNICAMP, quando fui introduzida à problemática Guarani e dei início a uma pesquisa etnográfica em Cacique Doble, no Rio Grande do Sul (Mello, 1998). Na dissertação de mestrado trabalhei o tema dos deslocamentos territoriais analisando redes de parentesco e reciprocidade que orientam a circularidade Guarani (Mello, 2001). Em minha tese de doutorado, concluída em 2006, segui mapeando esta rede de aldeias, visitando um total de 35 aldeias nos estados de SC, RS, PR e SP, refletindo sobre temas ligados às imbricações entre xamanismo, parentesco e transformação (Mello, 2006).

${ }^{2}$ O Programa de Formação de professores Guarani do sul e sudeste do Brasil Kuaá Mboé reúne 80 professores Nhandeva, Chiripá e Mbyá Guarani do sul e sudeste do Brasil. O tema das distinções entre etnônimos, subgrupos, parcialidades ou etnias Guarani do Brasil têm sido abordado em pesquisas feitas pelos professores indígenas. Os resultados obtidos por eles explicitam dinamicidade na construção destas categorias identitárias e provoca debates sobre o desaparecimento de alguns subgrupos registrados em suas histórias orais, o surgimento de novos e sobre divergências entre as categorias nativas de autodenominação dos subgrupos e os etnônimos utilizados pela sociedade nacional, por exemplo.

${ }^{3} \mathrm{~A}$ forma de grafar os nomes das etnias e as palavras em guarani do texto segue a maneira utilizada pelos professores da região da grande Florianópolis. É interessante registrar que devido à grande diversidade de alunos, formaram-se três correntes com distintas maneiras de escrever o guarani dentro do Programa de Formação de Professores Guarani. A minha escolha deve-se ao fato de meu aprendizado da língua guarani ter se dado inicialmente com o professor Geraldo Karai Okendá Moreira, da aldeia de Mbiguaçú, contudo, respeito e valorizo igualmente as outras duas formas.

${ }^{4}$ Vários professores desenvolvem pesquisas de resgate de palavras e expressões antigas que entraram em desuso em suas aldeias.

${ }^{5}$ Esta constatação foi feita por Joel, liderança Chiripá, que afirma haver "muito preconceito contra os Chiripá" por parte dos "djuruá". Segundo ele, em algumas oportunidades lhe foi dito que os Chiripá "não eram mais índios" e que apenas os Mbyá tinham direitos indígenas reconhecidos.

${ }^{6}$ Meu conhecimento da língua guarani não é suficiente para aprofundar a discussão sobre distinções dialetais. O que fica evidente a mim é que nas aldeias de RS, SC, PR eSP, há uma língua bastante semelhante entre si, com variações de vocabulário e sotaque, constatável até mesmo entre aldeias vizinhas. Estando acostumada a dialogar em aldeias habitadas pelos Chiripá e Mbyá brasileiros, encontro grandes dificuldade em compreender a fala dos Mbyá vindos do oeste, dos recém chegados ao Brasil e a fala dos Nhandeva.

${ }^{7}$ Conceito fundamental, o nhanderekó ou orerekó é o conjunto de normas e condutas de comportamento, de relações sociais, de produção, de práticas rituais etc. preconizadas pelas divindades criadoras da humanidade e que devem ser seguidas para a manutenção do equilíbrio social e cosmológico de uma tekoá (aldeia).

${ }^{8}$ Os deslocamentos territoriais dos Guarani são tratados na literatura clássica sobre 
o tema como "nomadismo" ou "migração", invariavelmente associados ao mito da Terra sem Mal. Atualmente os Guarani associam seus deslocamentos não como a busca pela terra sem mal propriamente, mas à busca de um lugar que propicie condições de vida condizentes com as prescrições divinas, o nhanderekó (Melià, 1990 e Mello, 2001). Estudos mais recentes sobre estes temas apontam outros aspectos da vida social e cosmológica associados a eles, não só na esfera do discurso, mas também na observação de eventos que os deflagram (Darella, 2004 e Litaiff, 1996). A problematização destes conceitos e os aspectos culturais e históricos envolvidos nestes movimentos têm sido enfatizados, gerando novos conceitos para defini-los, como "expansão territorial" (Brochado, 1969 e Noelli, 1996), "circularidade" (Diaz Martinez, 1991), "mobilidade" (Ladeira, 1992) etc.

9 "A gente está nesta terra não para ficar quieto, mas para se movimentar, fazer o eles que nos enviaram gostariam que a gente fizesse" (Perumi, liderança de uma família extensa que atualmente habita o litoral do RS. Colhido por Ciccarone, 1996: 216).

${ }^{10}$ Os Mbyá deslocam-se mais que os Chiripá na freqüência de mudanças e na extensão territorial que seus deslocamentos atingem. Os Mbyá atualmente habitam e circulam por áreas no Paraguai, Argentina, e no Brasil nos estados de RS, SC, PR, SP, RJ, ES, MG, MS, MA. Os Chiripá também deslocam-se frequentemente, no entanto, com menor intensidade. As circulações Chiripá dão-se por áreas no Paraguai, Argentina, e no Brasil pelos estados de RS, SC, PR, SP e RJ, configurando um território de deslocamento bem menos abrangente que dos Mbyá.

${ }^{11}$ Os Chiripá têm tomado a dianteira nas reivindicações de reconhecimento de seus territórios, garantidos na legislação brasileira a partir da promulgação da Constituição Federal de 1988, mas ainda não reconhecidos legalmente. Os Mbyá brasileiros têm acompanhado o movimento de reivindicação de seus direitos fundiários, mantendo-se por mais tempo em 0uma mesma terra. Entretanto, algumas lideranças mais idosas Mbyá e Chiripá, e os Mbyá vindos do Paraguai, ainda rechaçam a idéia de demarcação de suas terras, temendo a reprodução das políticas de confinamento e assimilação que foram praticadas pelo governo brasileiro nos séculos XIX e XX (Garlet, 1997).

\section{Referências}

ASSIS, Valéria e GARLET, Ivori. Análise sobre as populações Guarani contemporâneas: demografia, espacialidade e questões fundiárias. In: CALAVIA SÁEZ, Oscar (coord) Revista de Indias, Madrid, v.LXIV, n.230, 2004.

BARTOLOMÉ, Miguel A. Shamanismo y religion entre os Ava-Katu-ete. Cidade do México: Instituto Indigenista Interamericano, 1977.

BARROS, Valéria M. Da casa de rezas à Congregação Cristã no Brasil. O pentecostalismo Guarani na TI Laranjinha, PR. Dissertação (Mestrado em Antropologia social) PPGAS/UFSC, Florianópolis, 2003.

BROCHADO, José J.J.P. Histórico das Pesquisas Arqueológicas no Estado do Rio Grande do Sul. Rev. Iheringia. Porto Alegre, n.1, p.3-43, 1969. 
CICCARONE, Celeste. Revelações sobre a Terra: A memória viva dos Guarani. Vitória: EDUFES, 1996.

DARELLA, Maria Dorothea Post. Ore Roipota Yvy Porã. Territorialização Guarani no litoral de Santa Catarina. Tese (Doutorado em Antropologia). PUC/SP, São Paulo, 2004.

DIAZ MARTINEZ, Noemi. La migracion Mbyá Guarani. In: JORNA P. et al. (coords). Etnohistoria del Amazonas. Ecuador: ABYA-YALA/MLAL, 1991.

GARLET, Ivori J. Mobilidade Mbyá: História e Significação. Dissertação (Mestrado em história) - PUC/RS, Porto Alegre, 1997.

GOW, Peter. O Parentesco como consciência humana: O caso dos Piro. Mana, Rio de Janeiro, v.2, n.3, p.39-67, 1997.

LADEIRA, Maria Inês. O caminhar sob a luz - O território Mbyá a beira do oceano. Dissertação (Mestrado em Antropologia) - PUC/SP, São Paulo, 1992.

LITAIFF, Aldo. As Divinas Palavras: Identidade étnica dos Guarani-Mbyá. Florianópolis: EDUFSC, 1996.

MELIÀ, Bartomeu S.J. A Terra sem Mal dos Guarani: Economia e Profecia. Revista de Antropologia, São Paulo, v.33, 1990.

MELLO, Flávia Cristina de. Aspectos etnográficos da aldeia Guarani de Cacique Doble/ RS. Projeto de Pesquisa para o curso "Introdução à Etnologia Indígena". IFCH/ UNICAMP, Campinas, 1998.

. Aata tapé rupÿ - Seguindo pela estrada. Uma investigação dos deslocamentos territoriais realizados por famílias Mbyá e Chiripá Guarani no sul do Brasil. Dissertação (Mestrado em Antropologia Social) - PPGAS/UFSC, Florianópolis, 2001. . Aetchá Nhanderukuery Karai retarã. Entre Deuses e Animais: Xamanismo, Parentesco e Transformação entre os Chiripá e Mbyá Guarani. Tese (Doutorado em Antropologia Social) - PPGAS/UFSC, Florianópolis, 2006.

NIMUENDAJU, Curt. As lendas de criação e destruição do mundo como fundamentos da religião dos Apapokuva-Guarani. São Paulo: Hucitec-Edusp, 1987.

NOELLI, Francisco S. As hipóteses sobre o centro de origem e rotas de expansão dos Tupi. Revista de Antropologia. São Paulo, v.30, n.2, 1996.

SCHADEN, Egon. Aspectos Fundamentais da Cultura Guarani. São Paulo: EDUSP, 1974.

VIVEIROS DE CASTRO, Eduardo. Os pronomes cosmológicos e o perspectivismo ameríndio. Mana, Rio de Janeiro, v.2, n.2, p.115-144, 1996.

Recebido em 20 de dezembro de 2006.

Aprovado para publicação em 18 de dezembro de 2006. 
